\title{
Moving Ahead: Finding Opportunities for Transactional Training in Remote Legal Education
}

Jen Randolph Reise

Mitchell Hamline School of Law, jen.reise@mitchellhamline.edu

Follow this and additional works at: https://open.mitchellhamline.edu/mhlr

Part of the Legal Education Commons

\section{Recommended Citation}

Reise, Jen Randolph (2021) "Moving Ahead: Finding Opportunities for Transactional Training in Remote Legal Education," Mitchell Hamline Law Review. Vol. 47 : Iss. 1 , Article 2.

Available at: https://open.mitchellhamline.edu/mhlr/vol47/iss1/2

This Article is brought to you for free and open access by the Law Reviews and Journals at Mitchell Hamline Open Access. It has been accepted for inclusion in Mitchell Hamline Law Review by an authorized administrator of Mitchell Hamline Open Access. For more information, please contact sean.felhofer@mitchellhamline.edu. (c) Mitchell Hamline School of Law

$\mathrm{MH}$ Mitchell | HAMUINE OPEN ACCESS Solod fir the mitchellhamline.edu 


\title{
MOVING AHEAD: FINDING OPPORTUNITIES FOR TRANSACTIONAL TRAINING IN REMOTE LEGAL EDUCATION
}

\author{
Jen Randolph Reise
}

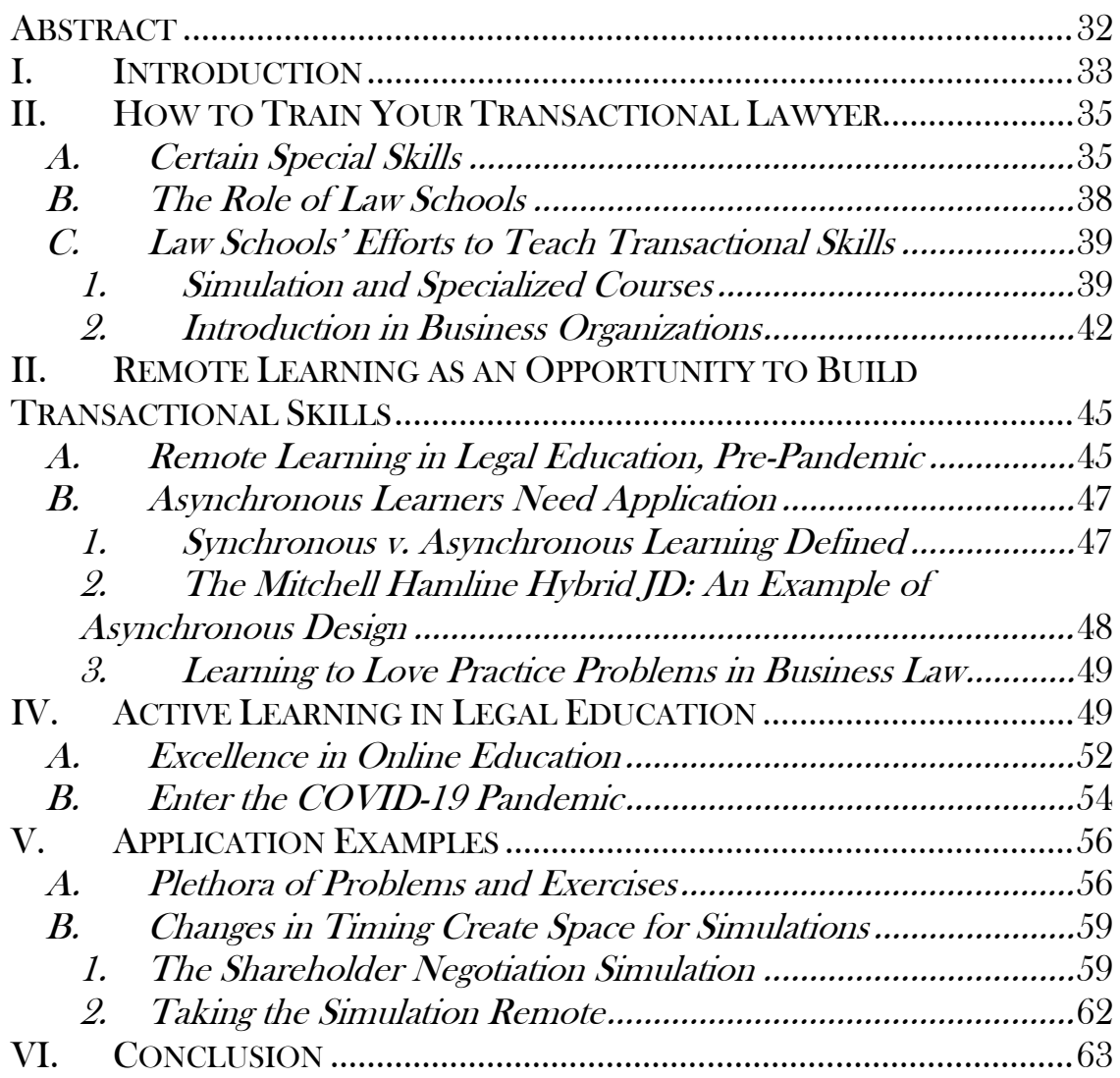

\begin{abstract}
This article builds on the many calls for teaching business acumen and transactional skills in law school with a timely insight: the shift to remote legal education creates opportunities to do so, in particular by incorporating practice problems and mini-simulations in doctrinal courses. Weaving together the literature on emerging best practices in online legal education, cognitive psychology, and the science of teaching and learning, Professor Reise argues that adding formative assessments and experiential education

${ }^{\ddagger}$ Visiting Professor at Mitchell Hamline School of Law; securities and corporate governance attorney by training, with experience in private practice at Taft and in-house as an Assistant General Counsel. Many thanks to Professors Leanne Fuith and Jessica Erickson for their faith and guidance on making my transition to teaching and now to academic writing about teaching and to third-year law student, Emily Gullickson, for her research assistance. Any errors are my own.
\end{abstract}


is effective in teaching and is critical in remote learning.

Offering vivid examples from her experience teaching Business Organizations online, she urges legal instructors to use the opportunity presented by the shift to remote education to incorporate problems and simulations as an effective way to motivate students to prepare for class, to expose them to transactional practice skills, and to effectively teach them key doctrinal concepts.

\section{INTRODUCTION}

The shift to remote legal education caused by the COVID-19 pandemic has presented many obstacles for students and law teachers, but there are opportunities as well.' ${ }^{\prime}$ For example, legal educators are reevaluating how they teach en masse and thinking deeply about what they want their students to learn from their courses. ${ }^{2}$

Separately, for years critics have alleged traditional legal education fails to effectively prepare students for transactional practice. ${ }^{3}$ Other scholars and American Bar Association (ABA) studies have concluded that law schools should be more deliberate in training students to be transactional lawyers. ${ }^{4}$ Recommendations include adding problem sets, exercises, and exposure to practice in both doctrinal courses, such as the fundamental Business Organizations class, and developing in-depth deal simulation or writing-intensive courses for small cohorts of third-year law students. ${ }^{5}$

Now is the perfect time to revisit those calls for change. This article illustrates ways in which remote learning presents opportunities to teach doctrinal business law in innovative, pedagogically sound ways. Specifically, the new challenge of developing quality online and hybrid legal education creates opportunities to include transactional skills in doctrinal courses in two crucial ways.

\footnotetext{
'For purposes of this article, I generally use "remote" to mean learning that is not in the same physical classroom, whether synchronous or asynchronous, and I use both "blended" and "hybrid" to mean a class in which some of the synchronous time is remote and some is face-to-face. I acknowledge that these terms are imprecise and are also being used in different ways during this time of change and upheaval in legal education, including by some of the sources cited herein.

${ }^{2}$ See, e.g., Jessica Erickson, Designing an Inclusive \& Supportive Classroom Environment Preparing for Fall Teaching in Physically Distanced, Hybrid, or Remote Courses, PrawfsBlawg (Aug. 21, 2020), https://prawfsblawg.blogs.com/prawfsblawg/remotephysically-distanced-teaching/ [https://perma.cc/PH9A-F9Q7].

${ }^{3}$ See, e.g., Therese H. Maynard, Teaching Transactional Skills Through Simulations in Upper-Level Courses: Three Exemplars, 10 TenN.J. Bus. L., 23, 27 n.15 (2009); discussion infra Section II.A.

'See, e.g., Barbara Wagner, Defining Key Competencies for Business Lawyers, 72 Bus. L. 101, 105 (2016) [hereinafter Key Competencies]; discussion infra Section II.B.

See infra Section II.C.
} 
First, asynchronous learning lends itself to the thoughtful use of exercises and problem sets as low-stakes assessments with opportunities for feedback. Both activities can expose students to working with documents, interpreting statutory defaults, and performing other key transactional activities.

Second, law teachers can use the larger blocks of time created by blended schedules to incorporate simulations into the core curriculum. In this paper, I describe a multi-day simulation used in my blended Business Organizations course to teach corporate control, transactional skills, and business law concepts. In fall 2020, I will move this simulation entirely online. In this paper, I explore how I intend to make this online transition.

I argue simulations and exercises are not additive to law school curriculum but are key components of hands-on learning in the doctrinal classroom, especially online. Other Business Organizations teachers facing additional semesters online may be looking to use a flipped-classroom approach and incorporate problem sets or exercises. ${ }^{6}$ I urge them to do so as an effective means to motivate students, facilitate class preparation, expose students to transactional practice skills, and teach key doctrinal concepts.

Part I canvasses the literature discussing the lack of training in transactional skills in traditional law school pedagogy, revealing two primary approaches described in the literature to improve those skills: first, the development of specialized simulation courses that immerse students in a semester-long deal simulation, and second, adding transactional exposure in the ubiquitous Business Organizations course. ${ }^{7}$

Part II turns to remote and blended learning: explaining synchronous, asynchronous, and flipped classrooms, as well as the mostly asynchronous design of the Mitchell Hamline Blended Learning (originally called Hybrid JD) ${ }^{8}$ program in which I teach. ${ }^{9}$ Tracing my own journey of understanding the importance of formative assessments in online learning, Part III summarizes insights from cognitive psychology research and the science of teaching and learning. I then explain the mechanisms behind active learning, trace the development of emerging best practices in pockets of legal education before the COVID-19 pandemic, and note the pandemic's dramatic impact in forcing all United States legal education online abruptly in the middle of the spring 2020 semester. ${ }^{10}$ Part III

\footnotetext{
"See infra notes 86-88 and accompanying text (explaining "flipped learning").

See infra notes 12-78 and accompanying text.

${ }^{8}$ Throughout the course of this article, this program will be referred to as the "Hybrid JD," as blended learning is frequently repeated in reference to mixed online and in-person education.

${ }^{9}$ See infra notes 79-92 and accompanying text.

${ }^{10}$ See infra notes $94-123$ and accompanying text.
} 
concludes that the new challenge of moving legal education online calls for the urgent implementation of pedagogical shifts that were already being tested and requires that instructors design their courses for active learning. Furthermore, I argue that doing so maximizes law schools' ability to effectively and efficiently teach core doctrinal and practical skills.

Finally, Part IV provides specific examples from my own experience teaching transactional skills through hybrid and remote Business Organizations courses." This part breaks into two sections. First, I explain how I use problem sets and exercises strategically as formative assessments to improve students' learning and expose them to transactional practice. Second, I note a shift to hybrid or remote learning can create blocks of time appropriate for intensive simulations, even in a doctrinal course. I also detail the multi-day, three-way shareholder negotiation deal simulation I use to teach my Business Organizations students concepts of corporate control and minority rights, negotiation, and other transactional practice skills.

\section{How to Train Your Transactional LaWyer}

\section{A. Certain Special Skills}

Over the past several decades, significant discussion among faculty and practitioners has explored the question of how to prepare law students to become transactional lawyers and litigators. ${ }^{12}$ It reflects a growing recognition that practicing as a transactional lawyer requires distinct skills and competencies, but these skills and competencies have not been traditionally taught in law school. Instead, the skills are learned when students become junior associates in transactional practice at a large firm, where associates are assigned to support partners in a specialized practice area (such as Mergers \& Acquisitions or Corporate Finance). In working closely with those partners, new lawyers learn that narrow practice area on the job.

In an instructive article, Professor Afra Afsharipour described her first assignment as a first-year associate: drafting and negotiating a credit agreement, having never seen a credit agreement and without any knowledge of their important terms. ${ }^{13}$ As she rapidly learned transactional practice from the partners at her firm, she reflected:

\footnotetext{
"See infra notes 124-138 and accompanying text.

${ }^{12}$ See generally Ronald Gilson, Value Creation by Business Lawyers: Legal Skills and Asset Pricing, 94 YALE L.J. 239, 241 (1984) (demonstrating the discussion on preparing law students to become transactional lawyers by asking "What do business lawyers really do?"); see also Key Competencies, supra note 4, at 102-03.

${ }^{13}$ Afra Afsharipour, Incorporating "Business" in Business Law Classes, 8 U.C. Davis Bus. L.J. 1, 2-3 (2007).
} 
Why was there so little emphasis on the language of finance and the general business knowledge necessary for budding business lawyers.? Why was there so little discussion about the lawyer's role in representing corporations? If we were to perform so much due diligence, why was there no introduction to this task in law school? Why had we never looked at a contract in any class? Why had we never reviewed a corporation's charter or bylaws in the corporations course? And the questions went on. It struck me that my law school education had taught me how to think like a lawyer (perhaps even just a litigator), but had given me little of the skills and vocabulary needed to be successful in the practice of transactional law and few tools to help me think creatively about possible answers to issues at the intersection of law and business. ${ }^{14}$

Others have identified this formidable gap between law school training and transactional practice in similar terms. ${ }^{15}$ Professor Tina Stark explained, "litigators use the analytic skill that we teach in our first-year courses. . . . The analytic skill of deal lawyers stands this paradigm on its head. ${ }^{16}$ In other words, an entirely different way of approaching the practice of law is necessary, not just exposure to transactional practice norms and documents. As Professor Constance Wagner explained:

Business lawyers are problem solvers and planners. They are forward-looking and engaged in preventative lawyering. They add value to transactions by advising their clients on the best ways to achieve their objectives as expeditiously as possible, at the lowest cost, and without taking undue risk. Their goal is to maximize private ordering and to minimize government involvement in the form of litigation or investigations. ${ }^{17}$

In 2016, a fulsome report by Barbara Wagner, on behalf of the ABA Business Law Section called Defining Key Competencies for Business Lawyers, endeavored to identify the specific professional skills, values, and behavioral competencies of business lawyers. ${ }^{18}$ The 2016 report found ten

\footnotetext{
${ }^{14} I d$. at 3 (emphasis in the original).

${ }^{15}$ Professor Therese Maynard reports hearing from hiring partners that law students are "virtually helpless in executing the tasks that the senior lawyer expects of a junior lawyer who is helping the senior lawyer staff a particular financing transaction." Maynard, supra note 3, at 27 n. 15 .

${ }^{16}$ Tina L. Stark, Thinking Like a Deal Lawyer, 54 J. Legal Educ. 223, 223-24 (2004).

${ }^{17}$ Constance Z. Wagner, Training the Transactional Business Lawyer: Using the Business Associations Course as a Platform to Teach Professional Skills, 59 ST. LouIS U. L.J. 745, 749 (2015) (internal footnote omitted).

${ }^{18}$ Key Competencies, supra note 12, at 102-03 (building on the broader identification of
} 
essential professional skills for business lawyers: problem-solving (including in the context and setting of the client's situation, such as in their business and industry), legal analysis and critical thinking, working with legal materials and research, factual investigation, communication, counseling, negotiation, dispute resolution, organization and management of legal work, and recognizing and resolving ethical dilemmas. ${ }^{19}$ The 2016 report also identified professional values of the business lawyer, which largely mirror those of the profession as a whole, plus twelve behavioral competencies of business lawyers, including "strives to add value to the deal" and "makes a deal." ${ }^{20}$

Other commentators help narrow the analysis to focus on how law school can help future lawyers build these necessary skills. Professor Eric Chaffee proposed six key points of business knowledge for new law school graduates, including financial literacy, basic business terminology, and basic transactional drafting skills. ${ }^{21}$

One important insight from commentators is that transactional practice is document-driven. ${ }^{22}$ Thus, law students need exposure to reviewing and preparing the documents they will see in practice. ${ }^{23}$ More broadly, Professor Wagner calls out four crucial transactional skills among the ten professional skills in Defining Key Competencies for Business Lawyers: contract drafting, client interviewing, counseling, and negotiatingnoting the last three require student simulations, rather than just learning them intellectually, to fully develop these skills. ${ }^{24}$ I believe Professor

fundamental lawyering skills and competencies set out by an 1992 ABA report known as the "MacCrate Report."). In the 2016 ABA Business Law Section report, Wagner used the terms transactional lawyer and business lawyer interchangeably, and endeavored to define the types of practice these lawyers practice, including: "advising on or assisting with choice of entity, governance issues, contract drafting, regulatory compliance, transactional work (including asset purchases and sales, financing (loans, leases, and equity), mergers, acquisitions, and joint ventures), and securities law and corporate compliance." Key Competencies, supra note 12, at 103.

${ }^{19}$ Id. at $115-38$.

${ }^{20}$ Id. The report also includes a helpful comparison back to the MacCrate Report as Appendix I. Id. at 151-55.

${ }^{21}$ Eric C. Chaffee, Answering the Call to Reinvent Legal Education: The Need to Incorporate Practical Business and Transactional Skills Training into the Curricula of America's Law Schools, 20 STAN. J.L. BUS. \& FIN. 121, 153 (2014) (noting also that law school graduates should understand "the benefits and drawbacks of the commonly available business forms," laws related to employees, and career options in business).

${ }^{22}$ David M. Epstein, Helen S. Scott, Carole Heyward \& Daniel B. Bogart, Simulations in Clinics, Contract Drafting, \& Upper-Level Courses, 12 TransaCtions: Tenn. J. Bus. L. 55, 65 (2011).

${ }^{23}$ Maynard, supra note 15 , at 32.

${ }^{24}$ Wagner, supra note 17, at 755-56 (citing Eric J. Gouvin, Teaching Business Lawyering in Law Schools: A Candid Assessment of the Challenges and Some Suggestions for Moving Ahead, 78 UMKC L. REv. 429 (2009); Joan MacLeod Heminway, Lyman Johnson \& 
Afsharipour summarized it best by suggesting that to be effective transactional attorneys, young lawyers need knowledge of business terms and finance to understand transactional context (including the client's business and their goals), and to use forms and precedents effectively. ${ }^{25}$

\section{B. The Role of Law Schools}

For various reasons, law schools are increasingly called upon to train law students in transactional practice skills rather than relying on infirm training. First, firms are under pricing pressure, making it more difficult to train junior associates as they work through the meandering process of current client matters; clients balk at paying for the work of first-year associates on their files; and firms do not want to write off the six-figure salaries of first-year associates. ${ }^{26}$ Second, training through mentorship was always a feature of big firms. However, most new JDs, especially from nonelite law schools, start their careers at small or medium firms. ${ }^{27}$ Additionally, the number of graduates starting out as solo practitioners has doubled since the 2008 recession. ${ }^{28}$ Thus, most new JDs are not, in fact, receiving the benefit of training through mentorship they would experience at a large firm.

The ABA joined the call for law schools to better prepare new lawyers for practice, including more emphasis on skills training and teaching approaches that go beyond the traditional "Socratic method." ${ }^{29}$ For hiring in law firms, legal knowledge and analysis alone are now described as "table

Michael Woronoff, Innovative Transactional Pedagogies, 12 Transactions: Tenn.J. Bus. L. 243 (2011)).

${ }^{25}$ Afsharipour, supra note 13, at 1-6.

${ }^{26}$ Wagner, supra note 17, at 757; accord Gouvin, supra note 24, at 452; Key Competencies, supra note 4, at 108 .

${ }^{27}$ Key Competencies, supra note 4, at 108 (explaining in 2014 that the trend towards small and medium firms had accelerated since the financial crisis).

${ }^{28}$ James G. LeIPOLd, NAT'L AsSOC. FOR L. Placement, JOBS \& JDs: EMPLOYMENT FOR The

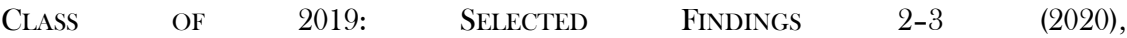
https://www.nalp.org/uploads/Classof2019SelectedFindings.pdf [https://perma.cc/89K2LQF5] (finding that the single largest share of law firm jobs for new JDs is firms of 1-10 lawyers).

* See, e.g., E. Eugene Clark, Legal Education and Professional Development-An Educational Continuum, Report of the Task Force on Law Schools and the Profession: Narrowing The Gap, 4 Legal Educ. Rev. 201, 221 (1993); William M. Sullivan, Anne Colby, Judith Welch Wegner, Lloyd Bond \& Lee S. Schulman, Educating Lawyers: Preparation for the Profession of LaW 4 (Carnegie Foundation for the Advancement of Teaching 2007) [hereinafter Carnegie Report], http://archive.carnegiefoundation.org/publications/pdfs/elibrary/elibrary_pdf_632.pdf

[https://perma.cc/4PEL-8PYQ]; $\quad$ AM. $\quad$ BAR ASs'N TASK FORCE ON The Future of Legal Educ., Report AND Recommendations 4 (2014), http://www.americanbar.org/content/dam/aba/administrative/professional_responsibility/re port_and_recommendations_of_aba_task_force.authcheckdam.pdf [https://perma.cc/2THB-ZTS2]. 
stakes," assumed minimums requiring supplementation if an associate is to excel..$^{30}$ In sum, law students must graduate more "practice-ready" than previous generations, which requires exposure to business acumen, transactional practice, and transactional skills.

Third, a significant portion of new JDs work in a variety of other fields instead of practicing law. The National Association of Law Placement (NALP) reported that 12.5 percent of students in the 2018 class were in socalled "JD Advantage Jobs" as of March 15, 2019, about half of whom were in the business sector. ${ }^{31}$ Growth is especially strong in compliance jobs, which do not require bar passage, but legal training is preferred. ${ }^{32}$

Furthermore, future employment opportunities for JDs continue to evolve. Professor Chaffee proposed in 2014 that law schools should prepare students to be human resources specialists, management analysts, health services managers, medical records technicians, and financial advisors. ${ }^{33}$ Mark Cohen of Legal Mosaic believes a substantial portion of future law school graduates will serve as "crisis managers, legal process designers, project managers, supply chain experts, data analysts, risk managers, coders, entrepreneurs, and legal technologists." ${ }^{34}$ Thus, whether they find employment as business lawyers or businesspeople, new lawyers need fundamental business knowledge. ${ }^{35}$

\section{Law Schools' Efforts to Teach Transactional Skills}

\section{Simulation and Specialized Courses}

Law schools have responded to the call to train students in business

\footnotetext{
${ }^{30}$ Mark Cohen, Skills And Education For Legal Professionals In The 2020's, Forbes (July 1, 2020), https://www.forbes.com/sites/markcohen1/2020/07/01/skills-and-education-forlegal-professionals-in-the-2020s/\#7477d7d72702 [https://perma.cc/NRE4-DYRB] (arguing that lawyers also need "business and data-analytics basics, project management, and a grasp of how technology is applied to legal delivery," as well as soft skills such as emotional intelligence and effective communication).

${ }^{31}$ Danielle A. Taylor, Nat'l Assoc. for L. Placement, Employment Rate Continues to Improve; Total Number of Law Firm Jobs Increases for First Time in Five Years 1-4, (2018), https://www.nalp.org/uploads/SelectedFindingsClassof2018_FINAL.pdf

[https://perma.cc/5MPF-RD69]. Taylor primarily defines JD advantage jobs as jobs that are "JD preferred" but do not require a JD or bar passage, and do not involve practicing law (excluding both private practice and in-house employment). Id. at 2. This article also notes that JD advantage jobs doubled as a share of employment with the impact of the recession from 2007-2016 (to 14 percent) and then began to decrease in 2017 and 2018. Id.

${ }^{32} I d$. at 2.

${ }^{33}$ Chaffee, supra note 21, at 127.

${ }^{34}$ Cohen, supra note 30.

${ }^{35}$ Chaffee, supra note 21, at 171. Professor Chaffee suggests that law schools should at a minimum, require a course on basic business terminology and financial literacy, transactional drafting, and business associations. Id.
} 
knowledge and transactional skills in several ways. Many have created upper-level courses that simulate a deal, such as the "Deals" program at Columbia Law School, ${ }^{36}$ the semester-long "Business Planning" simulation at Loyola-Los Angeles, ${ }^{37}$ and the international transaction simulation at American University's Washington College of Law, ${ }^{38}$ which negotiates a particular transaction with a law school class based in Scotland. ${ }^{39}$ In such simulations, groups of students represent a client in a hypothetical fact pattern and must negotiate the terms of a merger, acquisition, or investment (colloquially, a "deal" might involve any of these), hopefully, one that is favorable to their client and grounded in the law. ${ }^{40}$

Other schools have focused on transactional drafting as a key ingredient in an upper-level transactional course, like Professor Joan Heminway's Corporate Finance course at the University of Tennessee School of Law. ${ }^{41}$ Some have launched courses focused on entrepreneurship and the law, while others have partnered with business schools to teach law students MBA fundamentals or allow students to advise entrepreneurs. ${ }^{42}$

Simulations have immense value. They offer opportunities for

${ }^{36}$ Corporate, Business, and Transactional Law, Columbia L. ScH. (2020), https://www.law.columbia.edu/areas-of-study/corporate-business-and-transactional-law [https://perma.cc/WJ77-8QQ8].

${ }^{37}$ Business Planning: Financing the Start-Up Business and Venture Capital Financing, LOYOLA L. SCH. https:/www.lls.edu/academics/experientiallearning/transactionallawyeringinstitute/courseoff erings/ [https://perma.cc/B297-S6GS].

${ }_{38}$ Trade, Investment and Development Program, Am. Univ. (2020), https://www.wcl.american.edu/impact/initiatives-programs/trade/courses/transactions/ [https://perma.cc/VU5V-BCUQ].

${ }^{39}$ Victor Fleischer, Deals: Bringing Corporate Transactions into the Law School Classroom, 2002 Colum. Bus. L. Rev. 475, 490 (2002) (describing the Deals coursework at Columbia Law School); Maynard, supra note 15, at 23 (describing the development at Loyola Law School-Los Angeles of an upper-level Business Planning course as the capstone of the Business Law Practicum to prepare students to be transactional lawyers); Daniel Bradlow \& Jay Finkelstein, Training Law Students to be International Transactional Lawyers-Using an Extended Simulation to Educate Law Students about Business Transactions, 1 J. Bus. ENTREPRENEURSHIP \& L. 67, 72 (2007).

${ }^{10}$ For a full discussion of the deal simulation in my Business Organizations class, see infra Section IV.B.

${ }^{4}$ Heminway et al., supra note 24, at 244-45. Professor Joan Heminway describes how she teaches Corporate Finance as an advanced drafting course, including what resources she uses and the outcomes she looks for. $I d$.

${ }^{12}$ See also Anthony J. Luppino, Minding More Than Our Own Business: Educating Entrepreneurial Lawyers through Law School-Business School Collaborations, $30 \mathrm{~W}$. New Eng. L. Rev. 151 (2007); See generally Anthony J. Luppino, Can Do: Training LAWyers to Be EFFECTIVE COUNSElors to ENTREPRENEURS - REPORT TO THE EWING MARION KAUFFMAN FOUNDATION (2008), https://papers.ssrn.com/sol3/papers.cfm?abstract_id=1157065 [https://perma.cc/GM4S9LYS]. 
experiential learning by engaging students in designing solutions for both business and legal issues. ${ }^{43} \mathrm{~A}$ deal-focused simulation is an effective way for students to learn the various stages of a deal: from initial term sheet and due diligence to negotiation of full deal documents and closing. ${ }^{.4}$ In a class setting, deal simulations allow students to practice producing documents created at the various stages of a deal, including the type of writing expected of a transactional lawyer, which is very different from the writing traditionally expected on a final exam. ${ }^{45}$ Similarly, a commercial leasing simulation might require students to review a lease from their client's perspective and prepare a lease amendment, building skills in working with documents. ${ }^{46}$

Depending on the simulation, students may also practice other transactional skills, such as interviewing the client to establish facts or negotiating with an opposing party. ${ }^{47}$ Hands-on learning demonstrates that knowing both the law and the document provisions intimately is central to effective negotiation. ${ }^{48}$ Furthermore, simulations expose students to the transactional lawyer's special role as advisors and guides to their clients. ${ }^{19}$

Simulations are also an excellent way to teach business terminology and practices. By putting students in the shoes of a businessperson or their counsel, a simulation allows students to develop empathy and understanding of the business world, to which they may have no prior exposure. ${ }^{50}$ They teach professionalism and professional norms. For example, simulations can model the transactional attorney's role as part of a team alongside investment bankers, tax advisors, or in-house counsel, as well as the expectations within a law firm. ${ }^{51}$ Simulations can help students learn the norms for interacting with opposing counsel in a transactional context. ${ }^{52}$ In sum, simulations let students make mistakes and learn from

\footnotetext{
${ }^{43}$ Maynard, supra note 15 , at 31 .

"Id. at 31.

${ }^{45}$ Id. at 31-33.

${ }^{46}$ Epstein, et al., supra note 22, at 68. Professor Bogart describes his commercial leasing course where students draft, review, and negotiate leasing contracts in a simulated scenario. Id. at $67-68$.

${ }^{47} I d$. at 59-61. Professor Scott describes her creation of an upper-level Business Transaction Planning course which simulates the formation and funding process for a startup business. Students interview "clients," negotiate as different characters in the simulation, and draft documentation. Id. at 61 .

${ }^{18} I d$. at 66 (describing the need for transactional attorneys to both know the law and truly understand the documents necessary to the practice).

${ }^{49}$ Maynard, supra note 15 , at 31.

${ }^{50}$ Gouvin, supra note 24, at 443.

${ }^{51}$ Maynard, supra note 15, at 33-34.

${ }^{52}$ Gouvin, supra note 24, at 451 (describing a mistake Professor Gouvin made in early practice: sending a very one-sided deal to opposing counsel, to which opposing counsel responded with their own deal, teaching Gouvin that controlling the document is a vital vantage point).
} 
them while still in law school, helping students bridge the very real gap between law school, the bar exam, and practicing as a transactional lawyer. ${ }^{53}$

At the same time, a full-semester simulation or intensive writingfocused course serves only a small number of students at a law school. These courses necessarily have small enrollments due to the intense engagement and instructor feedback required. ${ }^{54}$ Thus, they become a tremendous opportunity for a few students who are already certain they want to practice transactional law and have the time in their last year of law school to dedicate to such a course in light of their other courses and commitments.

\section{Introduction in Business Organizations}

It is interesting to consider whether and how transactional approaches can be taught earlier in the curriculum and to a broader group of law students. Business Organizations presents one such opportunity, a class routinely taken by second-year law students and one which Professor Wagner calls "fundamentally transactional in nature." ${ }^{35}$ Depending on the law school, this fundamental class may also be called Business Associations (BA), Introduction to Business Organizations ${ }^{56}$ or split into two classes via its constituent parts of Agency \& Unincorporated Business Entities and Corporations. ${ }^{57}$

Under any name, Business Organizations covers multiple forms of business enterprise (types of partnerships, Limited Liability Corporations (LLCs), corporations, etc.) and teaches students about the powers and duties of their controlling persons (in the corporate case: directors, officers, and shareholders) ${ }^{58}$ Most law students take Business Organizations because these concepts are routinely covered in the bar exam, ${ }^{59}$ and it is required or

\footnotetext{
${ }^{53}$ Maynard, supra note 15, at 26-27.

${ }^{5 t}$ Epstein, et al., supra note 22, at 67. Bogart says he enrolls sixteen to twenty students in his simulation course, and sixteen "is a lot for this type of course." Id. Borden believes such a class should contain a maximum of twenty-five students. Bradley T. Borden, Using the Client-File Method to Teach Transactional Law, 17 CHAP. L. REv. 101, 116 (2013). Maynard's capstone business transactions planning course expanded to enroll seventy-two students by teaching five sections. Maynard, supra note 3, at 30. Interestingly, Maynard explicitly set out to design a program that could serve a larger number of students than a clinical approach could accommodate. $I d$.

${ }^{55}$ Wagner, supra note 17 , at 759.

${ }^{56}$ This is the title given to the course at Mitchell Hamline School of Law, where I teach-a name which I assume was meant to convey that we have time to only scratch the surface of the complexities of business organizations in a three-credit course.

${ }^{57}$ William J. Carney, Remarks at the AALS Conference on Business Associations: The Role of the Basic Course: What is it and Where is it Going? (June 8, 2009).

${ }^{58} I d$.

${ }^{59}$ See Preparing for the MEE, NAT'L. CONF. OF BAR EXAMiners, http://www.ncbex.org/exams/mee/preparing/ [https://perma.cc/TQW8-J5BX]; see also California Bar Exam: Business Associations - Scope, UC Hastings Coll. L. - S.F. (July
} 
strongly recommended at most U.S. law schools. ${ }^{60}$ It is generally a prerequisite for higher-level transactional and business law courses, such as Mergers and Acquisitions, Securities Regulation, Corporate Finance, or a Business Law Clinic. ${ }^{61}$ The Business Organizations course creates an opportunity to expose law students to transactional practice fundamentals.

A key strategy for embedding transactional practice exposure into an existing doctrinal course is to include the use of problem sets, which is also one of the recommendations of the Clinical Legal Association's 2007 report Best Practices for Legal Education: A Vision and a Road Map. ${ }^{62}$ Professor Wagner explains the problem-set method requires students to apply their knowledge to hypothetical fact patterns, thus testing their understanding of the rule and how it would be applied to those novel facts. ${ }^{63}$ These are legal skills needed in many types of law practice. ${ }^{64}$ Problem sets can also introduce students to the transactional skills of planning to mitigate risk and advising in grey areas (for example, by identifying the best available alternative).$^{65}$

As Professor Wagner explains, "I am not attempting to turn a doctrinal course into a professional skills course, but rather to introduce students to transactional law and to reverse the backwards approach to business law that is often the result of following the traditional approach to law teaching. ${ }^{{ }^{6} 6}$ In other words, the casebook method teaches business law by looking back on what failed, but business lawyers have to extract rules and plan accordingly. Reframing the use of cases to ask students how the parties could have avoided the litigation is also an effective way to teach both contract drafting and risk mitigation. ${ }^{67}$

28, 2020), https://libguides.uchastings.edu/ca-bar-exam/business-associations [https://perma.cc/7C2J-XU3C] (setting out common subject areas for testing within the Business Associations category).

${ }^{60}$ Catherine L. Carpenter, A Survey of Law School Curricula: 2002-2010, 33, 68 (2012) (showing that forty-one out of 166 law schools that responded to a 2010 survey of ABA accredited law schools in the United States required a Business Associations course and that another ninety-one highly recommended it).

${ }^{61}$ See, e.g., Maynard, supra note 15, at 36 (explaining that Business Associations is a prerequisite for the simulation-based Business Planning course).

${ }^{62}$ Wagner, supra note 17 , at 753.

${ }^{63}$ Id. at 753-54. Professor Wagner also notes that the Best Practices report recommends using simulations, role-playing, and experiential learning in the law school classroom. Id. at 754. See generally Roy Stuckey, Best Practices for Legal Education: A Vision And A ROAD MAP (2007), https://www.cleaweb.org/Resources/Documents/best_practicesfull.pdf [https://perma.cc/Q4ZF-FRF6] (discussing best practices for legal education based on studies and conversations with those in the legal profession and legal academia).

${ }^{61}$ Wagner, supra note 17 , at 762 .

${ }^{65} \mathrm{Id}$. at $762-63$.

${ }^{66} I d$. at 761 .

${ }^{6}$ Id. at 764 . 
Structuring problem sets to allow students to begin learning to work with contractual language develops an integral skill required of transactional lawyers ${ }^{68}$ Many casebooks now include problems, and some include sample documents, such as sample Articles of Organization for an LLC and a Partnership Agreement. ${ }^{69}$

Exercises can also introduce the use of form documents and convey the concept of statutory defaults. Professor Wagner describes an exercise where students must determine whether form documents conform to statutory requirements and how revisions could meet client objectives described in a fact pattern. ${ }^{70}$ Hypothetical client facts impress upon students that there is no perfect contract. Instead, the transactional lawyer tailors their work product to meet their client's objectives and situation.

This concept can be expanded by using the case-file approach, in which students might receive a packet of documents, such as a memo with background information about a client, preliminary research, and past agreements. ${ }^{71}$ Professor Bradley Borden describes a similar approach he calls the client-file method, combining the law school case method and the business school case-study method. ${ }^{72}$

The client-file method is especially apt for transactional practice because it exposes students to the forms of real documents they will encounter in practice, which teaches students to analyze agreements and exposes them to both strong and weak drafting. ${ }^{73}$ Professor Eric Gouvin extends his use of this approach into his final exam, which requires students to work with documents and financial statements. ${ }^{74}$ In other words, welldesigned client-file exercises can become essentially mini-simulations within a doctrinal course, imparting more briefly the many important lessons of simulations. ${ }^{75}$ Other strategies used by business law professors include inviting guest speakers from the transactional bar to give real-world perspectives on the issues being learned in class. ${ }^{76}$

However, while additions of simulations, exercises, problems, and speakers are valuable, the fact remains that time is limited. Business

\footnotetext{
${ }^{68}$ Epstein, et al., supra note 22, at 65.

${ }^{69}$ I have been using the Sjostrom casebook, in part because it has each of these features. William K. Sjostrom,Jr., Business Organizations: A Transactional ApProach (2d ed. 2016).

${ }^{70}$ Wagner, supra note 17 , at 765-66.

"Gouvin, supra note 24, at 441 (noting that this approach was pioneered by Professor Douglas Leslie at the University of Virginia School of Law).

${ }^{72}$ Borden, supra note 54 , at 101 .

${ }^{73}$ Id. at 108 .

${ }^{74}$ Gouvin, supra note 24, at 442.

${ }^{75}$ See supra notes 43-5253 and accompanying text.

${ }^{76}$ Gouvin, supra note 24, at 446-47; see also Wagner, supra note 17, at 766 (noting the importance of inviting guest speakers each semester to discuss the transactional process).
} 
Organizations is a fundamental bar course with a great deal of substantive law for students to learn. Practicing big-firm lawyer and adjunct Professor Michael Woronoff concluded that, while he supported adding transactional skills development to law school, the opportunity cost was too high to do so in Business Organizations because, "unless extra class time is added, much is sure to be lost by merely adding skills training to an existing course." ${ }^{\text {"77 }} \mathrm{I}$ disagree, as discussed below. ${ }^{78}$

\section{REMOTE LEARNING AS AN OPPORTUNITY TO BUILD TRANSACTIONAL SKILLS}

\section{A. Remote Learning in Legal Education, Pre-Pandemic}

In mid-March 2020, the COVID-19 pandemic swept through the United States. Halfway through the spring semester, law faculty faced the unexpected challenge of moving their classes online with little warning and scant training in remote teaching and learning. The resulting scramble towards "emergency remote teaching" was not ideal, but it demonstrated a valiant effort to pivot and continue teaching during a pandemic using hurriedly assembled resources. ${ }^{79}$

However, planned remote teaching and learning already existed in a few law schools, including Mitchell Hamline School of Law in St. Paul, Minnesota, where I have taught Introduction to Business Organizations

\footnotetext{
${ }^{77}$ Michael A. Woronoff, What Law Schools Should Teach Future Transactional Lawyers: Perspectives from Practice, UCLA SCH. L. 1, 14 (2009) (quoting his prior work with regard to Gordon Smith's similar point). Compare Michael A. Woronoff, Using a Venture Capital Class to Teach Transactional Skills (Oct. 30, 2008), http://ssrn.com/abstract=1292477 [https://perma.cc/3AAR-ES88] (referring to Woronoff's prior work), with Gordon Smith, The ABA's "Out of the Box" Committee on Legal Education, The Conglomerate Blog (May 16, 2009), https://www.theconglomerate.org/2009/05/page/3/ [https://perma.cc/KM75JL39] (noting Smith's similar point).

${ }^{78}$ See infra note 123 and accompanying text.

${ }^{79}$ Articles and places to share advice quickly sprang up. See Larry Cunningham, Moving to Best Practices in Online Learning, Law Sch. Assessment (Mar. 24, 2020), https://awschoolassessment.org/2020/03/24/moving-to-best-practices-in-online-learning/ [https://perma.cc/FZF6-S4KZ]; William Fisher, Emergency Online Pedagogy (Mar. 14, 2020), http://fisherip.org/emergency-online-pedagogy/ [https://perma.cc/5XSP-G3UG]; Pandemic Pedagogy: Law Teaching in a Time of COVID-19, FACEBOOK, https:/www.facebook.com/groups/679162509600230/ [https://perma.cc/Z454-YBB5]. The term "emergency remote teaching" was used widely, including by four law professors with prior experience teaching online. See Susan Landrum, Allie Robbins, Melissa Hale \& Natalie Rodriguez, Intersections Between Deliberate Online Pedagogy and Emergency Remote Learning, CALICON2020 (June 3, 2020), http://2020.calicon.org/pandemic/sessions/intersections-between-deliberate-onlinepedagogy-and-emergency-remote-learning [https://perma.cc/RJ34-WXFA].
} 
mostly-online since fall $2018{ }^{80}$ Mitchell Hamline was the first law school to launch a "blended learning" (online and in-person) law school program originally called the "Hybrid JD" program, launched under a variance from the ABA in January 2015. ${ }^{81}$ Several other law schools subsequently developed blended learning JD programs before the COVID-19 pandemic, including Syracuse University in January $2019 .{ }^{82}$ The pedagogical research of remote teaching and learning conducted in the undergraduate setting and lessons learned from the chaotic spring 2020 semester can assist in developing more carefully planned remote legal education in the future.

In fact, as I explain below, remote learning presents an opportunity to introduce law students to transactional documents and skills as part of the regular curriculum in two crucial ways. First, asynchronous learning is much more effective when teachers include exercises and other applications of the material. Second, the blocks of time often created by blended and remote scheduling allows for greater use of simulations, even within doctrinal classes. I describe one such simulation in some detail-a shareholder negotiation exercise I have conducted multiple times at Mitchell Hamline's in-person Capstone Week as a key part of my Introduction to Business Organizations course. ${ }^{83} \mathrm{I}$ then discuss how I adapted this simulation for a remote, synchronous Capstone in fall 2020.

\footnotetext{
${ }^{80}$ I say "mostly-online" for two reasons: first, because within the design of the Mitchell Hamline Hybrid JD program, I teach asynchronously and online for all but one intensive week we call Capstone. See infra notes 89-90 and accompanying text. Second, while I started by teaching in the Hybrid JD program, before the COVID-19 pandemic hit, I also taught Introduction to Business Organizations in a traditional face-to-face format and in the Mitchell Hamline Blended Weekend program, which was face-to-face every other weekend with asynchronous components on the other weeks, as well as other classes among these various formats.

${ }^{81}$ Jordan Friedman, Law Schools Explore Partially Online Learning, U.S. NEWs \& WORLD REP. (Nov. 7, 2016), https://www.yahoo.com/news/law-schools-experiment-partially-onlinelearning-143000557.html [https://perma.cc/2C76-BRCN]. The program, as well as the ABA variance that allowed it, is described in detail by Professors Eric S. Janus, Gregory M. Duhl Simon Canick, William Mitchell College of Law's Hybrid Program for J.D. Study: Answering the Call for Innovation, 83 B. Examr. 28 (2014). The authors, and Jim Hilbert, deserve the credit for designing the capstone week and its use of multi-day simulations to teach both doctrine and practical skills, as described in Part II of this paper.

${ }^{82}$ Stephanie Francis Ward, If Taught Well, Online Law School Courses Can Pass the Test, Experts Say, ABAJ. (Feb. 6, 2019), https://www.abajournal.com/news/article/are-online-lawschool-courses-good-that-depends-experts-say [https://perma.cc/NY5S-GLHP]; see also Paul Caron, Akron is Tenth Law School to Offer Hybrid OnlineJ.D., TaxProf Blog (Nov. 4, 2019), https://taxprof.typepad.com/taxprof_blog/2019/11/akron-is-tenth-law-school-tooffer-hybrid-online-jd.html [https://perma.cc/TA2T-V6QN]. Syracuse calls its program "JDinteractive" to stress the synchronous approach. About JDinteractive, SYracuse U., https://jdinteractive.syr.edu/about-jdinteractive/ [https://perma.cc/FG23-Z8PN].

${ }^{83}$ See infra Section V.B.1.
} 


\section{B. Asynchronous Learners Need Application}

\section{Synchronous v. Asynchronous Learning Defined}

First, a baseline must be defined: what is meant by synchronous and asynchronous learning? Synchronous learning is the delivery of information by the teacher in real-time, regardless of whether the teacher and student are in-person or remote (e.g., on Zoom). ${ }^{84}$ When students are in class and listening to faculty lecturing or leading a discussion through the Socratic method, whether face-to-face or via Zoom, this is synchronous learning.

Asynchronous learning, on the other hand, reflects the time the student spends working independently. In a traditional law school classroom, students are expected to spend multiple hours reading the assigned cases before class in order to discuss them there; this is an asynchronous component of the traditional pedagogical approach. ${ }^{85}$ In other words, synchronous instruction is "real-time," and asynchronous is "on your own time."

The "flipped classroom" approach has become common in undergraduate and kindergarten through 12th-grade classrooms in the past decade. ${ }^{86}$ Here, students are instructed to complete readings or watch videos before class (asynchronous), and class time is then used for application exercises and discussion (synchronous). ${ }^{87}$ At its core, "[f]lipping ... is a tool to help move the classroom toward active learning, and a better use of face-to-face time. ${ }^{\$ 8}$

In sum, regardless of delivery method, a course of study usually involves both synchronous and asynchronous learning. An effective teacher or program plans the course elements and determines which elements they will have students cover in which way. Designing a remote course allows

\footnotetext{
${ }^{81}$ Cunningham, supra note 79; see also Leslie Larkin Cooney, Judith Karp, Maggie Finnerty \& Howard E. Katz, More Pedagogic Techniques: Online Exercises \& Integrating Skills Into Different Kinds of Courses, 10 Transactions: Tenn. J. Bus. L. 389, 390 (2009).

${ }^{85}$ Cunningham, supra note 79; see also infra note 95 and accompanying text (describing the Socratic method).

${ }^{86}$ See, e.g., Stephen Noonoo, Why Flipped Learning Is Still Going Strong 10 Years Later, EDSURGE (Oct. 3, 2017), https://www.edsurge.com/news/2017-10-03-why-flipped-learningis-still-going-strong-10-years-later [https://perma.cc/6DQX-SMYB] ("The promise of more time for active learning is key to the flipped appeal, its fans say. Equally important, the approach offers a readymade solution to a universal problem: In the information age, how do you teach students to think for themselves when so many answers are just a Google search away?"). This article also notes that active learning is highly compatible with other techniques, including project-based learning. Id.

${ }^{87}$ Id.

${ }^{88}$ Id. (quoting Aaron Sams, a high school chemistry teacher and vocal proponent of the flipped classroom).
} 
both re-imagination of what should be synchronous versus asynchronous and access to additional technologies.

\section{The Mitchell Hamline Hybrid JD: An Example of Asynchronous Design}

The creators of Mitchell Hamline's Hybrid JD program made specific choices to develop a program that part-time law students juggling full-time jobs and living anywhere in the world could complete. ${ }^{89}$ Specifically, students must come to St. Paul for intensive periods (generally two weeks a semester in the first years, and less thereafter depending on class choices). ${ }^{90}$ The other weeks of the 14-week semester are fully asynchronous. Each week, students watch pre-recorded lectures, do readings, or complete an assignment applying class material, such as a discussion post or a problem set.

These weekly formative assignments serve multiple functions. First, they force students to stay up to date in the class to complete the assignments. As an instructor, it is immediately obvious which students do not turn in the weekly assignment at all and easy to identify students who are struggling with the week's material. The use of multiple formative assessments also arises from best practices in teaching and learning research (not online learning specifically), which have found that students learn best

\footnotetext{
${ }^{89}$ See supra note 81 and accompanying text (discussing the variance received by the ABA in order to launch the program); see also Kenneth R. Swift, The Seven Principles for Good Practice in [Asynchronous Online] Legal Education, 44 Mrtchell Hamline L. Rev. 105 (2018) (describing Swift's Employment Law and Transactional Drafting courses in the Mitchell Hamline Hybrid JD program). Professor Swift explains how asynchronous courses allow his non-traditional students to balance jobs and family by choosing when during the week they can interact with the course. Id. at 157-58. Mitchell Hamline and its predecessor schools have long provided opportunities for adult professionals to go back to law school while working, including a long-standing part-time evening program that includes Supreme Court Justice Warren Burger among its graduates. See Michatl J. Graetz \& Linda Greenhouse, The Burger Court And the Rise of The Judicial Right (2016); see also History, Mitchell Hamline SchoOl OF Law, https:/mitchellhamline.edu/about/history/ [https://perma.cc/372L-AEX8]. Mitchell Hamline's blended learning program, synonymous to their hybrid program, builds on that history by creating a modern way for working professionals to go to law school, and now to do it while living anywhere. For most of the semester, students work through the course remotely, and they intermittently travel to campus for intensive periods. Most of these students are already juggling demanding jobs and families, and they live all over the country and even internationally. I have had students who live in rural areas, intermittently move with military spouses, or frequently travel for work (e.g. airline pilots), none of whom could have gone through a traditional law school program.

${ }^{90}$ For more information on this program and its requirements, including some shift in its name and parameters over time, see Mitchell Hamline School of Law, Blended Learning at Mitchell Hamline, https://mitchellhamline.edu/academics/j-d-enrollmentoptions/blended-learning-at-mitchell-hamline/ [https://perma.cc/5ZAM-CLHF].
} 
by having multiple opportunities to practice and receive feedback on that practice. ${ }^{91}$ Thus, quite unlike the traditional law school model, where 100 percent of the class points come from the final exam, the majority of the points in many Hybrid JD classes come from small weekly assignments and a few larger assignments (perhaps a paper or midterm).

\section{Learning to Love Practice Problems in Business Law}

When planning my first year taking over the teaching of Introduction of Business Organizations in the Hybrid JD program, I struggled to identify thirteen exercises, problems, or discussion questions to assign. It was such a departure from the traditional law school teaching model, and I did not want to waste my students' time or my own with busy work or questions that simply tested whether they had, in fact, done the reading. Eventually, with some mentoring as well as trial and error, I realized well-designed problems and exercises are a terrific way to teach Business Organizations. I have imported this approach back into my more traditional and synchronous classes. Below are specific examples of how I have successfully integrated problems and exercises into Business Organizations, especially in an online or hybrid format. ${ }^{92}$

Before getting into those weeds, however, let me make a possibly controversial point. Including problems and exercises in Business Organizations not only introduces students to transactional skills, but this exposure also increases learning of the doctrinal concepts by invoking important principles of active learning. ${ }^{93}$

\section{ACTIVE LEARNing IN LEgal EduCATION}

Experts on legal education have described active learning methods as anything beyond listening to a lecture, including applying the law to short hypotheticals, interviewing and advising a client, arguing a motion, or defending student positions. ${ }^{94}$ The last of these, of course, is a key feature

\footnotetext{
${ }^{91}$ Linda B. Nilson \& Ludwika A. GoOdson, Online Teaching at Its Best: Merging Instructional Design with Teaching and Learning Research 8, 13 (2017) (discussing teaching and learning principles developed by educational researchers). See infra notes 94-108 and accompanying text (providing more information on teaching and learning principles research).

${ }^{92}$ See infra Section V.

${ }^{93}$ See, e.g., supra note 77 and accompanying text (noting an assertion that there is too much material in Business Organizations to have time for practice problems).

${ }^{94}$ See Yvonne M. Dutton, Margaret Ryznar \& Kayleigh Long, Assessing Online Learning in Law Schools: Students Say Online Classes Deliver, 96 Denv. L. Rev. 493, 527 (2019); Elizabeth Seul-gi Lee \& Anneka Ferguson, The Development of the Virtual Educational Space: How Transactional Online Teaching Can Prepare Today's Law Graduates for Today's Virtual Age, 6 European J.L. \& Tech. 1, 14-16 (2015); Martin Pritikin, Online
} 
of the traditional "case-method" approach to law school teaching, also called the "Socratic method." ${ }^{95}$ However, both pedagogy experts and the ABA's various recommendations on improving legal education encourage law faculty to use more active learning elements in their classrooms and move away from a purely Socratic teaching method..$^{96}$

Cognitive psychology and the science of teaching and learning can inform law teaching as well. The research demonstrates the value of lowstakes practice in order to learn new material and retain it for the future. ${ }^{97}$ Teachers can harness the power of the "testing effect" by using low-stakes assignments and quizzes requiring students to generate answers and applications for themselves, rather than just receiving information. ${ }^{98}$ Retention is enhanced by "spaced" repetition, meaning review over time, ${ }^{99}$

Law School Course Development: 4 Takeaways for Success, Concond L. SCH. (Apr. 4, 2019), https://www.concordlawschool.edu/blog/news/online-law-school-coursedevelopment-4-takeaways/ [https://perma.cc/F6WY-V9XT]; Swift, supra note 89, at 138-39.

${ }^{95}$ Swift, supra note 89, at 116-17 (providing a detailed description of the Socratic method); see also Borden, supra note 54, at 101; Dutton et al., supra note 94, at 498-99 (explaining that for more than a hundred years, legal education has focused on this one model to the exclusion of all others); Jessica Erickson, Experiential Education in the Lecture Hall, 6 NE. L. REv. 87, 93 (2013) [hereinafter Erickson, Experiential Education] (discussing Professor Stephen Bainbridge's description of a colleague's approach as "soft Socratic" which "demands far less of students than the traditional Socratic approach").

${ }^{96}$ Often, this discussion is framed as a new emphasis on "experiential education," as in the Carnegie Report (Sullivan ET AL., supra note 29) now reflected in the ABA Standards requiring experiential courses as part of an ABA-accredited program. Wagner, supra note 17, at 105 (discussing ABA Standard 303(a)(3)); ABA Section OF Legal Educ. \& Admissions to the Bar, ABA Standards and Rules of Procedure for Approval of LAW SCHOOLS 2016-2017 (2016), https://www.americanbar.org/content/dam/aba/publications/misc/legal_education/Standard s/2016_2017_aba_standards_and_rules_of_procedure.authcheckdam.pdf [https://perma.cc/5RSJ-NNDX].)

${ }^{97}$ NillSON \& GOODSON, supra note 91, at 80-106 (canvassing the research literature).

${ }_{98}^{9}$ Id. at 92-93 (citing Henry L. Roediger, III \& Andrew C. Butler, The Critical Role of Retrieval Practice in Long-term Retention, 15 Trends in Cognitive SCI. 20, 20 -27 (2011); Mark A. McDaniel, Daniel C. Howard \& Gilles O. Einstein, The Read-Recite-Review Study Strategy: Effective and Portable, 20 Psychol. ScI. 516, 516-22 (2009); Henry L. Roediger, III \& Jeffrey D. Karpicke, The Power of Testing Memory: Basic Research and Implications of the Educational Practice, 1 Perspectives on Psychol. SCI. 181, 181-210 (2006)).

${ }^{99}$ Nilson \& GoOdson, supra note 91, at 91 (discussing Peter C. Brown, Henry L. Roediger III \& Mark A. McDaniel, Make It Stick: The Science of Successful Learning (2014); Andrew C. Butler, Elizabeth J. Marsh, J. P. Slavinsky \& Richard G. Baraniuk, Integrating Cognitive Science and Technology Improves Learning in a STEM Classroom, 26 Educ. PoL'Y REv. 331, 331-40 (2014); Nicholas J. Cepeda, Harold Pashler, Edward Vul, John T. Wixted \& Doug Rohrer, Distributive Practice in Verbal Recall Tasks: A Review and Quantitative Synthesis, 132 Psychol. Bull. 354, 354-80 (2006); John Dunlosky, Katherine A. Rawson, Elizabeth J. Marsh, Mitchell J. Nathan \& Daniel T. Willingham, Improving Students' Learning with Effective Learning Techniques: Promising Directions from Cognitive and Educational Psychology, 14 Psychol. SCI. In THE Pub. InT. 4, 4-58 (2013); John Hattie, Visible Learning: A Synthesis of Over 800 Meta- 
and by the use of varied examples and stories. ${ }^{100}$ Furthermore, students benefit from quick and targeted feedback on their work. ${ }^{101}$ This feedback includes the ability to see and correct their own errors. ${ }^{102}$

We have all experienced these learning strategies as students and possibly as teachers. ${ }^{103}$ To the last point, we learn more from our mistakes than our successes. Most lawyers can describe an important lesson they learned by making a mistake: a missed deadline, a social blunder, a flubbed question in class. I missed a pub trivia question in 2000, which asked for a line of a classic rock song, and I remember that every time the song comes on the radio. As you would expect, I know the right answer deeply now. ${ }^{104}$ At the same time, I do not recall any of the questions I got right that evening at pub trivia. The point is that, as teachers, we can harness the power of learning through failure and make it work for our students and us by adding low-stakes opportunities to try for the right answers and give feedback

Analyses Relating to Achievement (2009); Doug Rohrer \& Harold Pashler, Recent Research on Human Learning Challenges Conventional Instructional Strategies, 39 EDUC. Researcher, 406, 406-12 (2010); Philip H. Winne \& John C. Nesbit, The Psychology of Academic Achievement, 61 Ann. Rev. Psychol. 653, 653-78 (2010)).

${ }^{100}$ NILSON \& GOODSON, supra note 91, at 81, 90 (discussing and citing Gordon H. Bower \& Michal C. Clark, Narrative Stories as Mediators for Serial Learning, 14 PsychonOMIC SCI. 181, 181-82 (1969); Arthur Graesser, S. R. Goldman \& P. van den Broek, Narrative IMPACT: SOCIAL AND COGNITIVE Foundations 229-262, (Melanie Green et al. eds., 2002); Karl Haberlandt \& Arthur C. Graesser, Component Processes in Text Comprehension and Some of Their Interactions, 114 J. EXPERIMENTAL PSYCHOL. GEN. 357, 357-74 (1985)).

${ }_{101}$ NiLSON \& GOODSON, supra note 91, at 81-84, 94, (discussing SUSAN A. Ambrose, Michael W. Bridges, Michele DiPietro, Marsha C. Lovett, Marie K. Norman, Richard E. MaYer, How Learning WORKS: SEven Research-Based Principles for Smart Teaching (2010)); Barbara Means, Marianne BaKia \& RoberT Murphy, Learning Online: What Research Telis Us about Whether, When, AND How (2014); Wanda Bonnel \& Heidi Boehm, Improving Feedback to Students Online: Teaching Tips from Experienced Faculty, 42 J. ConTinuing Educ. Nursing 503, 503-09 (2011); Doreen Gosmire, Marcia Morrison \& Joanne Van Osdel, Perceptions of Interactions in Online Courses, 5 J. Ondine Learning \& Teaching 609, 609-17 (2009); Kathryn Ley \& Ruth Gannon-Cook, Learner-Valued Interactions: Research into Practice, 15 Q. Rev. Distance Educ. 23, 23-32 (2014); Melanie Shaw, Teaching Through Feedback, Onune LEARNING CONSORTIUM (2016), https://secure.onlinelearningconsortium.org/effective_practices/teaching-through-feedback [https://perma.cc/VSJ7-L86L].

${ }^{102}$ NILSON \& GOODSON, supra note 91, at 82, 94 (noting that research illustrating calcium is released into the brain upon a realization of error, which enhances neuroplasticity and therefore learning) (citing Farzaneh Najafi, Andrea Giovannucci, Samuel S-H Wang \& Javier F Medina, Coding of Stimulus Strength via Analog Calcium Signals in Purkinje Cell Dendrites of Awake Mice, 3 ELIFE (2014)).

${ }^{103}$ Accord Bradlow \& Finkelstein, supra note 39, at 79 (describing what students learn from a deal simulation and how "[m]istakes are often the best teachers, and there is no better environment for making and learning from mistakes than a simulation.”).

${ }^{10 t}$ For the curious, the line is "blowing through the jasmine of my mind." SEALS \& CROFTS, Summer Breeze, on Summer BreEze (Warner Bros. Records 1972). 
explaining what the answers are. ${ }^{105}$ Practice problems are a perfect opportunity to do that.

I believe good teachers converge on what works, whether they have read the literature or use the same terms. Indeed, while the transactional lawyers-turned-law-professors introduced above explained their courses and assignments primarily in terms of building practical skills, I suspect they would agree assigning practical problems also reinforces doctrinal knowledge. ${ }^{106}$

Other principles of active learning are more clearly invoked by simulations and group work. Simulations not only allow an opportunity to develop deeper learning and practice through application, as hypotheticals and practice problems do, but also bring emotional intensity and multisensory learning to bear, enhancing student learning. ${ }^{107}$ Furthermore, simulations usually involve group work, and research has shown that working in small groups engages students. ${ }^{108}$

\section{A. Excellence in Online Education}

Law schools, in turn, began to design blended and remote programs that included and implemented active learning principles before the

\footnotetext{
${ }^{105}$ For more on the value of failure, see Professor Cat Moon's work at the Vanderbilt Law School's Program on Law and Innovation and its July 2019 "Failure Camp," which I described in Oh, the Places You Will Fail! A Letter From Failure Camp. Jen Randolph Reise, Oh, the Places You Will Fail! A Letter From Failure Camp, Thomson ReuTers LEGAL EXEC. InSTIT. (Aug. 12, 2019), https://www.legalexecutiveinstitute.com/failure-camp/ [https://perma.cc/8G5Y-GQGM].

${ }^{106}$ For example, Maynard explains that the simulated deal format of her Business Planning course "integrate[s] the teaching of new substantive learning about capital raising transactions with the development of the skills necessary for law students to hit the ground running as first-year corporate law associates." Maynard, supra note 15, at 31-32. More generally, the growing use of problems in doctrinal classes and textbooks demonstrate that law faculty see the value of application in cementing key concepts.

${ }^{107}$ NiLSON \& GOODSON, supra note 91, at 12 (discussing the six teaching and learning principles described by Diane Cummings Persellin \& Mary Blythe Daniels, A CONCISE GUIDE TO ImProving STUDENT LEARning (Stylus 2014)). These principles are: (1) Desirable difficulties enhance long-term retention; (2) Meaningful and spaced repetition enhances retention; (3) Emotional intensity and relevance deepen learning; (4) Multi-sensory learning deepens learning; (5) Small group work engages students; and (6) Low-stakes formative assessment enhances retention. Id.

${ }^{108} I d$. at 12 (discussing the six teaching and learning principles articulated by Persellin and Daniels, as well as other models that find group work effective, e.g., Chickering and Gamson's seven principles); see Arthur W. Chickering \& Zelda F. Gamson, Seven Principles for Good Practice in Undergraduate Education, 39 AM. Ass'N FOr Higher Educ. Bull. 37 (1987)). See also Lee \& Ferguson, supra note 94, at 21-22 (describing group work in the online law school classroom as meeting a best standard for education: "[O]nline courses should contain a blend of peer interactions and individual assignments to help balance the independent and collaborative creation of knowledge.").
} 
COVID-19 pandemic. While the value of active learning is by no means confined to online education, it is particularly important and obvious there.

The ABA accreditation standards allow limited experimentation, but accredited schools have experimented with a few online elements and variances. ${ }^{109}$ Pre-pandemic, the trend moved cautiously toward more remote and blended legal education, most recently with the ABA proposing (in 2016) and adopting (in 2018) a change to its accreditation standards, allowing the equivalent of a full year of online courses. ${ }^{110}$ In addition, unaccredited United States law schools have long embraced distance learning, playing an important role in developing methods and a testing ground for online legal education, as have non-American law schools. ${ }^{111} \mathrm{~A}$ 2019 study from Indiana University of Law summarized the literature surrounding remote legal education and surveyed their students finding successful online courses must be "organized, engaging, and provide[] opportunities for students to receive feedback on activities that assess their learning of the material and practice real-world skills." ${ }^{\prime \prime 2}$

When used in law schools, flipped classrooms (both remote and inperson) increase student engagement and incorporate practice opportunities in the classroom. However, their success depends significantly on the professor spending time planning and organizing the course before launch. ${ }^{113}$ Opportunities for formative assessment and timely feedback are critical. ${ }^{114}$ Creative approaches like full-class transaction simulations and

${ }^{109}$ See supra notes 81-82 and accompanying text (discussing variances received by Mitchell Hamline and Syracuse).

${ }^{110}$ Dutton et al., supra note 94, at 499-502 (2019) (detailing the history of Standard 306).

"'I Peter Sankoff \& Craig Forcese, The Flipped Law Classroom: Retooling the Classroom to Support Active Teaching and Learning, 119 Can. Legal Educ. Ann. Rev. 130-33, 130 (2015) (discussing the use of a "flipped classroom" in online education in Canadian law schools); Lee \& Ferguson, supra note 94, at 10-16 (discussing the development and use of simulated transactions in online classes in Australian law schools). Concord Law School, for example, is an unaccredited U.S. school and has been a leader in developing best practices in online legal education. See, e.g., Pritikin, supra note 94 (discussing design and implementation of online courses and Concord's program, including its competitive moot court team). See also Shaun Jamison, Community Building in Synchronous Classes Online, LINKEDIN (May 12, 2020), https://www.linkedin.com/pulse/community-buildingsynchronous-classes-online-jamison-jd-phd-cipp/ [https://perma.cc/N3NX-LY5A]. $\quad \boldsymbol{C}$. Dutton et al., supra note 94, at 499 (noting the difficulties ABA accredited law schools face when incorporating online learning).

${ }^{112}$ Dutton et al., supra note 94, at 498.

${ }^{113}$ Id. at 509-510; Sankoff \& Forcese, supra note 111, at 124-26; Shawn M. Boyne, Giving Students a Seat at the Table: Using Team-Based Learning in Criminal Law, 51 Ind. L. Rev. 440, 441, 444 (2018).

${ }^{114}$ Jack Graves, Formative Assessment as a Bridge Between Online and In-Person Learning, STRum COLL. L. (Sept. 27, 2019), https://www.law.du.edu/documents/conferences/ online/Formative-Assessment-as-a-Bridge-Between-Online-and-In-Person-Learning.pdf [https://perma.cc/2255-TCVP] (explaining the use of the flipped classroom and assessments 
working "in firms" have been tested online. ${ }^{115}$ Remote legal education works, and most programs use a combination of synchronous and asynchronous learning. ${ }^{116}$

To synthesize, much pre-COVID-19 pandemic discussion centered on ways the traditional legal education model should shift to accommodate stronger teaching and learning methods and build practiceready students. There were several common threads:

(1) adding formative assessments that build opportunities for practice and learning rather than a grade entirely based on the final exam;

(2) using simulations and skill-building exercises to expose students to real-world applications; and

(3) exposing students to transactional practice as well as litigation.

\section{B. Enter the COVID-19 Pandemic}

As many found in Spring 2020, a law teacher cannot simply deliver the same lecture followed by a discussion via Zoom as they planned to do in person and achieve the same results. The Socratic method, in particular, does not easily translate to a Zoom environment. ${ }^{117}$ The emergency shift

in online coursework); Pritikin, supra note 94 (recommending a mix of auto-graded and professor-graded assessments to balance speed with depth of feedback); Swift, supra note 89, at 140-45 (noting there have been calls for formative assessment in face-to-face legal education as well); Erickson, Experiential Education, supra note 95, at 101 (discussing the three types of assessments from Michael Hunter Schwartz, SOPHIE M. SPARrow \& Gerald F. Hess, Teaching Law by Design: Engaging Students from the Syllabus TO THE FinAL EXAM 135-164 (2009)).

${ }^{115}$ Lee \& Ferguson, supra note 94, at 10-11.

${ }^{116}$ I believe the seeming polar opposites of all-synchronous and asynchronous are already converging on a blend of what works. Syracuse has been a vocal proponent of synchronous online education, and yet upon a close look their program is $50 \%$ asynchronous. Professor Nina Kohn describes it as, "each week JD students spend half their class-time in online courses working through the interactive self-paced material and attend a live class with their professor for the other half." Nina A. Kohn, Teaching Law Online: A Guide for Faculty, J. Legal. Educ. 1, 3 n.3 (forthcoming 2020). At Mitchell Hamline, on the other hand, while most of the program is asynchronous, the intense Capstone week is synchronous, as are the weekly office hours held by most professors. Kohn notes research indicating that a blended approach is most effective for students: "A 2010 meta-analysis from the Department of Education found student outcomes were better for classes that blended online elements and face-to-face instruction, than for classes that were solely online or solely face-to-face. $I d$. at 8 n.17. See Barbara Means, Yukie Toyama, Robert Murphy \& Marianne Bakia Karla Jones, Evaluation of Evidence-Based Practices in Online Learning, U.S. DEPT. OF Educ. (Sept. 2010), https:/www2.ed.gov/rschstat/eval/tech/evidence-based-practices/finalreport.pdf [https://perma.cc/V7FT-TXRF]. I believe there is much common ground in asking what portions of a course could be asynchronous, and how to do that well. Professor Kohn's recent article has valuable advice to that point.

${ }^{117}$ See, e.g., Jessica Erickson, Preparing for Fall Teaching - Discussion and Socratic Dialogue in Physically Distanced, Hybrid, or Remote Courses, PrawfsBlawg (July 17, 2020), 
online left many law faculty racing to rise to this new challenge, both technologically and pedagogically. ${ }^{118}$ Their challenges included learning Zoom and the loss of the physical whiteboard, but much of the discussion focused on pedagogy. How do you know if your students understand what you are teaching them? How can you engage them over the distance? How can you assess their learning and respond to their needs? ${ }^{119}$ Indeed, the academy as a whole was now diligently interested in what a minority of law schools and law teachers had pioneered.

Many of the answers suggested moving parts of the course to an asynchronous format-in essence, exposing law teachers to the "flipped classroom" model..$^{120}$ As Professor William Fisher of Harvard Law School recommended in an immensely practical article published the same week many schools moved abruptly to remote learning, lecturing should take only one-third of the class time.

So-if one has to do something other than lecture, what should it be? Ideally, one would devote considerable time to moderated discussions of case studies or problems. As you are undoubtedly aware, studies of the relative efficacy of various modes of classroom instruction consistently find that students are much more likely to master and retain information and ideas when they put them to use-solving problems, debating their merits and applications, and so forth-than when they merely watch or listen to

\footnotetext{
https://prawfsblawg.blogs.com/prawfsblawg/2020/07/preparing-for-fall-teaching-discussionand-socratic-dialogue-in-physically-distanced-hybrid-and-remo.html [https://perma.cc/FZH5-Y7L2].

But see Kohn, supra note 116, at 14 (suggesting the Socratic Method can translate to the virtual classroom but requires modification for optimal virtual use).

${ }^{118}$ For example, a Facebook group called "Pandemic Pedagogy" grew so quickly that by March 14, 2020, a separate sub-group solely for law professors was created, called Pandemic Pedagogy: Law Teaching in a Time of COVID-19, FACEBOOK,https://www.facebook.com/groups/679162509600230 [https://perma.cc/QY2Q54YX]. This group had 836 members as of July 21, 2020. Similarly, the Center for Computer-Assisted Legal Instruction 2020 conference was moved online and held virtually on June 3-5, 2020, re-focused on legal education in a time of a pandemic. Sessions included "Easy Ways to Improve Your Class Videos" and "Synchronous or Asynchronous? Lessons Learned from Teaching During Covid.” Conference Agenda, CALICON (June 2020), http://2020.calicon.org/schedule, [https://perma.cc/JH7T-UXDC].

${ }^{119}$ Pandemic Pedagogy: Law Teaching in a Time of COVID-19, supra note 118.

${ }^{120}$ See, e.g., Allie Robbins, Thoughts for Law Professors Contemplating Moving to Virtual Classes, Passing THE BAR Blog (March 10, 2020), https://passingthebar.blog/2020/03/10/thoughts-for-law-professors-contemplating-movingto-virtual-classes/ [https://perma.cc/AB3G-98D4]; Bridget Crawford, Tips for Teaching Law Classes Online in the Event of a COVID-19 Shut Down of Law Schools, The Faculty LOUNGE (March 7, 2020), https://www.thefacultylounge.org/2020/03/tips-for-teaching-lawclasses-online.html [https://perma.cc/TAH6-H5S7].
} 
presentations of them. That generalization remains true with respect to online teaching .... In online teaching, it is even more important than in classroom teaching to have a well developed case, case study, or problem prepared in advance, which can then provide the focus for discussion. ${ }^{121}$

As the discussion turned to teaching remotely in fall 2020, with some preparation time over the summer, the consensus of most articles was that good remote teaching is good teaching, but it requires more preparation upfront to design engaging materials and activities aligned to defined course objectives. ${ }^{122}$

In sum, the challenge of moving legal education fully remote adds urgency to the implementation of pedagogical shifts already in the works and requires educators to design courses for active learning. Furthermore, doing so maximizes our ability to teach both core doctrine and practice skills efficiently and effectively. I do not believe it is a tradeoff, after all. ${ }^{123}$ As other Business Organizations teachers plan another remote semester, they may look to implement a flipped classroom approach and incorporate problem sets or exercises. I urge them to do so as an effective way to motivate students to prepare for class, expose them to transactional practice skills, and effectively teach them the doctrinal concepts.

\section{APPLICATION EXAMPLES}

\section{A. Plethora of Problems and Exercises}

I utilize several types of problem sets in my Business Organizations classes. First, we review sample agreements, some of which are in our casebook, and problems interpreting them. These force students to practice reading an agreement carefully to identify and apply relevant provisions. Furthermore, they must also apply the applicable statute to determine whether the contractual provisions effectively modify the statutory

\footnotetext{
${ }^{121}$ Fisher, supra note 79.

${ }^{122}$ Jessica Erickson, Preparing for Fall Teaching - Five Steps to Designing a Physically Distanced/Hybrid/Remote Course, PrawfsBlawg (July 8, 2020), https://prawfsblawg.blogs.com/prawfsblawg/2020/07/preparing-for-fall-teaching-five-steps-todesigning-a-physically-distancedhybridremote-course.html [https://perma.cc/NX4B7DW2]; see also Kohn, supra note 116, at 4 (recommending a synchronous approach to online teaching unless one is "willing and able to invest the time in carefully and deliberately designing and building engaging asynchronous content, and are prepared to incorporate and review applied learning activities (e.g., exercises, questions) into that content.”).

${ }^{123}$ See discussion of Woronoff, supra note 77 and accompanying text. Accord, Erickson, Experiential Education, supra note 95, at 88-89 ("Experiential learning is not just appropriate for the relatively few skills courses in law schools. It is the best way to teach all material in law schools, including doctrine ... . This Essay argues that the push for experiential education in law schools is really a push for better teaching.").
} 
defaults. ${ }^{124}$ Reading an agreement and statute together is, in my view, a key transactional skill, and we work on it throughout the semester.

In asynchronous classes, my students analyze assigned problems and submit answers by Saturday at midnight. Because grading causes a delay in feedback, I give them immediate access to a model answer once they have submitted their work. ${ }^{125}$ Students appreciate this opportunity to confirm or correct their understanding of the material immediately, while they are still focused on the assignment. These assignments are "knowledge-checks," meaning students get full points for submitting an answer demonstrating reasonable effort, even if some answers are wrong. ${ }^{126}$

In synchronous classes (either in-person or via Zoom), I generally use these same exercises and problems, but I work through them with the class in real-time, as I imagine most Business Organizations professors do. I have become very comfortable with a partially- synchronous model, where my students watch my lectures before class, and we use class time to discuss and do application work, a classic "flipped classroom" model. ${ }^{127}$ In the Zoom format, I utilize screen-sharing to display the relevant statute(s) for discussion, and I ask students to submit their answers to my questions in the chat to keep the class moving.

Additionally, I have designed several exercises to expose students to other aspects of transactional practice. In the first, students answer questions requiring them to explore state statutes and the Secretary of State website for their chosen state. For example, they must find where to file to form an LLC in their state, report on what information about corporations is publicly available, and consider whether their state follows the uniform statutes on various matters. Having discussed various uniform statutes and the Delaware code in class, this activity provides a helpful, real-world application that grounds theory in practical skills. Later, students complete an exercise designed to introduce them to searching through company filings in the Securities and Exchange Commission's "EDGAR" database. ${ }^{128}$

${ }^{124}$ For example, we may explore the steps necessary to transfer an interest from a partner to a third party, pursuant to a specific Partnership Agreement entered under the law of a state that follows the Revised Uniform Partnership Act (RUPA).

${ }^{125}$ See supra note 101 and accompanying text (discussing the importance of quick feedback). This can be set up to happen automatically through Canvas by making a submission a "required" task in Canvas in order to move on to the next module, and then setting up a second module with the model answer, which treats the prior module as a "prerequisite."

${ }^{126}$ See supra note 105 and accompanying text (discussing the importance of failure to the learning process).

${ }^{127}$ See supra notes 86-888 and accompanying text (discussing the flipped classroom model). ${ }^{128}$ EDGAR stands for Electronic Data Gathering, Analysis, and Retrieval system. Public companies are required to file registration statements, periodic reports, and a wide variety of other forms required by SEC rules and regulations on the searchable EDGAR system. See U.S. SEC. \& EXCH. COMM'N, Filings \& Forms, www.sec.gov/EDGAR.shtml [https://perma.cc/YZ3U-8P8M]. 
Students are routinely shocked by the breadth of information at their fingertips.

Another exercise reinforces how to resolve partnership issues and introduces the concept of negotiating through comments. Students receive a term sheet describing a partnership and a hypothetical set of facts, and then they must edit the term sheet to make it more favorable to their client. I developed this assignment, in part, as a laddering exercise to build skills they will need for the larger shareholder negotiation during the Capstone discussed below. ${ }^{129} \mathrm{I}$ also realized students require an explicit introduction to the transactional practice skills of comments and term sheets. ${ }^{130}$ Finally, students complete a simulated client letter in lieu of a midterm. In this assignment, they analyze a hypothetical scenario requiring them to apply agency law principles to advise their client about her exposure on several contract and tort issues.

As previously mentioned, I believe many Business Organizations classes include such assignments. My objective here is to explicitly note that Business Organizations teachers and casebook writers use them because they have found they work, even if they have not focused on the psychology and pedagogy research explaining why. Application exercises are powerful ways to build practical skills, especially the transactional skills that are scarce in law school, and use active learning principles to drive effective comprehension of doctrinal concepts through the testing effect, spaced repetition, and practice. ${ }^{131}$

I also want to stress that the shift to remote learning makes the application of these exercises more important than ever. ${ }^{132}$ Exercises like these require students to learn by doing and thus fit especially well into the design of a partially-asynchronous remote course where students are working independently. Students can take the time they need to review the materials, work through the application, and submit answers. Then the instructor reviews and provides feedback and can easily see who is tracking the material and who is struggling. ${ }^{133}$ Without interim assignments in remote education, it is all too easy for students to tune out or to struggle silently. In other words, adding formative assessments is not just effective teaching; it is critical in remote learning.

\footnotetext{
${ }^{129}$ See infra Section V.B.1 "The Shareholder Negotiation Simulation."

${ }^{130}$ See supra notes 43-54 and accompanying text (discussing the value of deal simulation courses in introducing these concepts).

${ }^{131}$ See supra notes 977-102 and accompanying text (discussing cognitive psychology of learning).

${ }^{132}$ See supra notes 103-116 and accompanying text (discussing emerging best practices in online legal education).

${ }^{133}$ See supra notes 89-90 and accompanying text (discussing design of the mostlyasynchronous Mitchell Hamline Hybrid JD).
} 


\section{B. Changes in Timing Create Space for Simulations}

In addition to the inclusion of problem sets and exercises to monitor and extend learning, a move to remote or blended learning also creates opportunities by breaking down the normal model of what a semester-long class looks like. Online courses may be shorter and more intensive, or they may run the course of an entire semester but include an intensive portion. This creates an increased opportunity to bring extended problem sets and simulations into a doctrinal classroom.

All but one week of the Mitchell Hamline Hybrid JD program is fully asynchronous. We call the remaining week Capstone, and as originally designed, it is an intensive, in-person week during which students from around the world travel to campus in St. Paul. Capstone is usually scheduled as the 12th or 13th week of the 14-week semester, so it lends itself to intensive application to integrate the material covered so far, including simulation.

In Business Organizations, I utilize a multi-day, three-party shareholder negotiation simulation to teach concepts of corporate structure, minority shareholder rights, and negotiation skills. Below, I explain the design of the simulation as used in the past and discuss the exercise. I then explore how I modified this simulation for a remote Capstone week in fall 2020.

\section{The Shareholder Negotiation Simulation}

My shareholder negotiation simulation is, in form, a client-file exercise that merges the law school case method with the business school case study method. ${ }^{134}$ This type of experiential learning forces students to actively apply and test what they have learned. ${ }^{135}$ Before Capstone, students spend twelve weeks learning the law of business organizations through casebook readings, pre-recorded lectures, and problem sets. In the week prior to Capstone, they read a chapter on minority shareholder protections describing concepts like buy-sell agreements, cumulative voting, and appraisal rights, and they view a lecture about control in the closely held corporation. During Capstone, we spend approximately half of the week on this single simulation, roughly two to three hours per day for four days.

In this exercise, I ask students to take the client file method one step further. They must determine key facts about their client's situation and their goals and then apply their findings to the concepts of corporations and

\footnotetext{
${ }^{134}$ See supra notes 72-75 and accompanying text.

${ }^{135}$ See supra notes 107-108 and accompanying text (discussing the value of experiential and simulation activities, and of small group work); see also Sarah Valentine, Flourish or Founder: The New Regulatory Regime in Legal Education, 44 J.L. \& EDUC. 473, 496-507 (2015) (describing the research underlying adoption of student-centered learning at the university level, and lessons for legal education).
} 
corporate control. Furthermore, they must actively negotiate for their client's goals against others in real-time. This is a challenging exercise. At the same time, it is rewarding; students consistently report it as a fun and extremely valuable part of the course.

I divide students into groups of six for the shareholder negotiation: a pair representing the founder ("Louise"), a second pair representing the other current owner ("Charlie"), and a third pair representing a private equity firm considering a major investment ("RT Capital”).

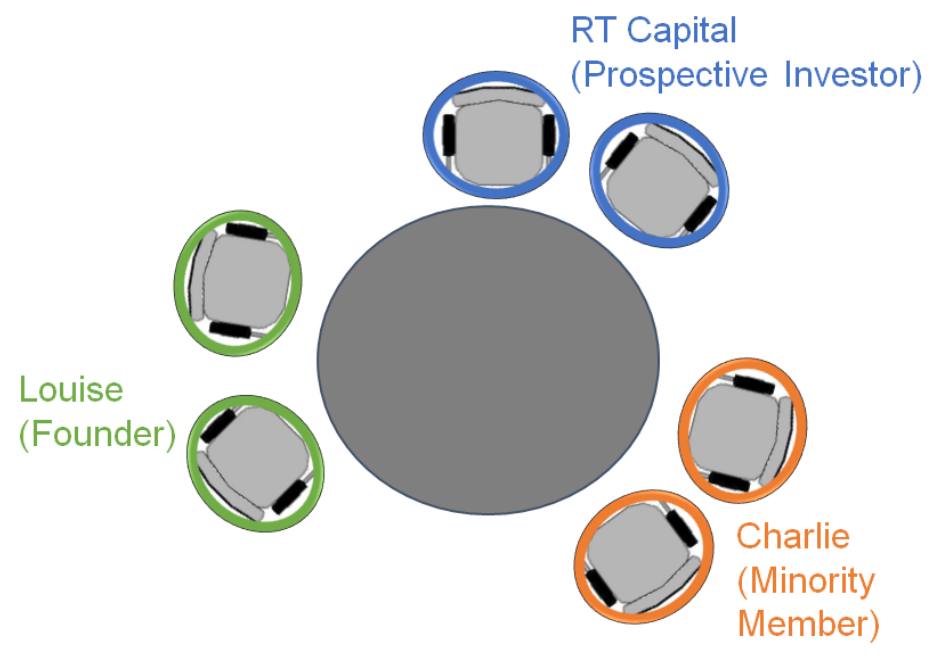

To lessen the cognitive burden somewhat, the business that Louise and Charlie own in the scenario is a food truck. This design gives students a business they can easily envision, and they are able to understand its potential revenues, costs, and risks. Furthermore, we use Louise and her food truck throughout the course. During the Agency unit, students write a client letter to Louise about potential liability for the contracts and torts of her agent, a part-time employee of the food truck. In studying Partnerships, students negotiate the terms of a partnership agreement with a new character, Charlie, a good employee with business acumen who is willing to invest in the business in return for becoming a partner. When we learn about LLCs, we discuss how much more protection an LLC provides and how to file an LLC for the food truck business. Thus, students feel a preexisting affinity for these characters and their business prior to entering this new and expansive scenario.

At Capstone, I introduce the Shareholder Negotiation scenario. Each student assumes the role of one of the three characters' attorneys. Next, they each receive a written scenario laying out recent business developments and their interest in raising capital. They also receive the current LLC Operating Agreement for the business and Louise and Charlie's relative ownership interests. 
On the first day, students break out into confidential group meetings with their clients to hear more about their priorities in a potential transaction before beginning to negotiate in their groups. The clients, of course, are played by my adjuncts helping with the simulation. The client meetings allow adjuncts to instruct students on the differing priorities and concerns of their clients and, most importantly, allow students to practice client interviewing skills.

Students are instructed to compromise to produce a non-binding, joint term sheet laying out the key terms of an investment by RT Capital by the end of the simulation on Friday afternoon. I tell them they will not be able to get everything their client wants but that instead, their goal should be to bring back the best deal available and see if it is acceptable to their client. ${ }^{136}$ Finally, students negotiate over the course of three days, and I tell them to figure out within their group how to turn the document overnight.

My students practice several important skills in this exercise. They identify relevant facts from the written simulation and the time with the client. They practice client interviewing skills, including asking questions to obtain important information about facts and priorities and practice representing a client in a transactional context. They also practice negotiation skills, including learning the additional complexity of a threeparty negotiation and navigating its treacherous alliances. They sometimes struggle to work as a pair on the same team, something that is rare in law school negotiations but very common in law firm practice. ${ }^{137}$ They are exposed to the need for sidebars, private meetings with a subpart of the main negotiation group.

It also effectively teaches key business law concepts. They learn what a term sheet is and what it means to turn a document. They integrate what they have learned about how a corporation functions, such as the roles of directors, officers, and shareholders and the decisions that each are entitled to make. ${ }^{138}$ They fully comprehend the previously dry information

${ }^{136}$ This contrasts with the approach described by some other deal programs, e.g. the International Business Transactions class at American University as described in Bradlow and Finkelsten's article, which notes about half of the simulations fail to reach a deal in time. Bradlow \& Finkelsten, supra note 39, at 81 n.26. I require them to produce a joint term sheet for two reasons: first, I found that students otherwise too easily threw up their hands and insisted they could not reach agreement, and thus restricted their learning, and second, in practice as a transactional lawyer it is the prerogative of the client to walk away from the deal, not the lawyer. I tell my students they will be presenting their negotiated term sheet to their client after the simulation as "the best deal available," so their clients can make the business decision whether this is acceptable (and, in reality, would likely negotiate further).

${ }^{137}$ As a side note, I also have them work in pairs to build in some redundancy, so a negotiating group does not lose a party if someone becomes ill, and to accommodate the reality of weaker students. It also helps to accommodate the large class sizes, so in a class of sixty I have ten negotiating groups to monitor rather than twenty.

${ }^{138}$ As I circulate among the groups, I hear them teaching each other, "The shareholders elect 
about minority shareholder protections and buy-sell rights by having to apply it through the lens of their client's perspective. At least a couple of my students always have the self-awareness and the courage to report on their class evaluations that they did not understand these concepts until they were forced to put them into practice.

In sum, these students are spending an intensive week in an introductory course getting many of the same benefits as a semester-long simulation course. Furthermore, instead of the benefits accruing only to an intimate group of 15 to 20 students, almost all of Mitchell Hamline's Hybrid JD students take this course. In fall 2019, I taught two sections of Hybrid Business Organizations and took 120 students through this simulation.

\section{Taking the Simulation Remote}

In fall 2020, Capstone will be entirely remote due to the ongoing COVID-19 pandemic and the difficulty and danger caused by students converging on St. Paul as originally planned. This presents new challenges, and perhaps new opportunities, for me as the instructor and for my students.

I plan to continue to do this simulation, largely synchronously, via Zoom. Zoom's breakout rooms feature should allow me to split up groups and continue to check in with the teams as they negotiate. ${ }^{139}$ I will encourage the students to sidebar using separate calls or Zoom sessions as needed. In addition, I expect the ability to "chat" with your partner during a negotiation may be helpful and avoid the need for some sidebars, akin to passing notes during a conference call.

I am concerned some students may have Internet access issues, family commitments, or illness preventing them from participating fully, or that students may be less willing to invest the significant time into Capstone when they are not physically on campus. I plan to have structured check-in questions at the beginning and end of each day to capture participation and nudge self-reflection (I did this during in-person Capstones as well). I will also encourage my students to let me or their group know about issues they experience, allowing for rebalancing of tasks as needed.

I am also musing about how this intensive face-to-face negotiation has never reflected modern transactional practice. Instead, in my practice experience, the negotiation happens through the comment process as lawyers email carefully marked up drafts back and forth. I am hesitant to

the board, and the board appoints the officers, so we have to ...” or I see them leafing back in the book for the difference between a tag-a-long and a drag-a-long provision.

${ }^{139}$ Breakout rooms allow the "host" of the meeting to assign groups of students to discussion groups, which is akin to breaking a class into small groups to work on a problem. See ZoOM HelP CTR., Enabling Breakout Rooms, https://support.zoom.us/hc/enus/articles/206476093-Enabling-breakout-rooms [https://perma.cc/U6KS-HN8Z]. 
move to this more asynchronous approach, however, because I see my students teaching each other so much and tossing many ideas back and forth. I suspect it would be hard to find the same integrative compromises in a couple of distanced turns.

In sum, the changing schedules created by online and hybrid learning open up opportunities to embed simulations in a larger course, such as Business Organizations. Doing so exposes a much larger population of students to the benefits of simulated transactional practice than those reached through a specialized third-year course.

\section{CONCLUSION}

In conclusion, graduating practice-ready lawyers today requires exposure to transactional practice rather than relying on law firms to train their first-year associates. Fortunately, remote and blended learning presents opportunities to introduce law students to transactional documents and skills as part of the regular curriculum in two crucial ways. First, asynchronous learning is much more effective when teachers include exercises and other application of the material. Second, the blocks of time often created by remote and blended scheduling allow for greater use of simulations even within doctrinal classes.

Other Business Organizations teachers who are planning another remote semester may look to use a flipped classroom approach and incorporate problem sets or exercises. I urge them to do so as an effective way to motivate students to prepare for class, to expose them to transactional practice skills, and to effectively teach them doctrinal concepts. 


\section{Mitchell Hamline Law Review}

The Mitchell Hamline Law Review is a student-edited journal. Founded in 1974, the Law Review publishes timely articles of regional, national and international interest for legal practitioners, scholars, and lawmakers. Judges throughout the United States regularly cite the Law Review in their opinions. Academic journals, textbooks, and treatises frequently cite the Law Review as well. It can be found in nearly all U.S. law school libraries and online. mitchellhamline.edu/lawreview

\section{$\mathrm{MH}$}

MITCHELL | HAMLINE

School of Law

(c) Mitchell Hamline School of Law 875 Summit Avenue, Saint Paul, MN 55105

mitchellhamline.edu 